\title{
FAKTOR YANG MEMPENGARUHI TERJADINYA PERNIKAHAN
} USIA DINI

\section{FACTORS AFFECTING THE OCCURRENCE OF EARLY MARRIAGE}

\author{
Wulan Angraini ${ }^{1}$, Bintang Agustina Pratiwi ${ }^{2}$, Henni Febriawati ${ }^{3}$, Riska Yanuarti ${ }^{4}$, Betri Anita ${ }^{5}$, Oktarianita $^{6}$ \\ 1,2,3,4,5,6 Fakultas Ilmu Kesehatan, Universitas Muhammadiyah Bengkulu \\ Jl. Adam Malik KM. 9, Kampus IV Muhammadiyah Bengkulu \\ Sido Mulyo, Gading Cempaka Kota Bengkulu, 38229, Indonesia \\ Alamat Korespondensi: Bintang Agustina Pratiwi \\ E-mail: bintangagustinap@umb.ac.id
}

\begin{abstract}
Bengkulu Tengah is one of the Regencies in Bengkulu Province with the highest number of marriages in the early age compared to the other nine regencies/cities, which amounted to 29.12 percent. This study aims to determine the factors that influence early marriage in Bengkulu Tengah District. This type of research is quantitative, the population were all married couples in January-September 2017. Sampling using Propotional Random Sampling technique with a total sample of 237 people. Data was collected using a valid and reliable questionnaire then analyzed using univariate and multivariabel analysis (Multiple Linear Regression Test). The result show that youngest age of marriage is 15 years, lowest income $R p$ 100,000, youngest menarche age 10 years, average knowledge score 6.19, attitude 29.43, media exposure 1.63, influence of friend 5, parental support 2.23, stigma 4.29. The factors that influence the occurrence of early marriage are knowledge, Age of Menarche, and Media ( $p$ value $<$ 0.05). The age of Menarche is the most influential factor in the age of marriage. The younger the age of menarche, the younger the age of one's marriage. It is better for teens who have experienced menstruation to maintain their reproductive health by delaying marriage in their teens.
\end{abstract}

Keywords: early marriage, knowledge, age of menarche, media

\begin{abstract}
ABSTRAK
Bengkulu Tengah adalah Kabupaten dengan angka pernikahan usia dini tertinggi di Provinsi Bengkulu sebesar 29,12\%. Penelitian ini bertujuan untuk mengetahui faktor yang mempengaruhi pernikahan usia dini di Kabupaten Bengkulu Tengah. Jenis Penelitian ini adalah kuantitatif, populasi pada penelitian ini adalah semua pasangan yang menikah pada bulan Januari-September 2017. Pengambilan sampel mengunakan teknik Propotional Random Sampling dengan jumlah sampel sebanyak 237 orang. Data dikumpulkan menggunakan kuesioner yang telah valid dan reliabel. Selanjutnya dianalisis menggunakan analisis deskripsi dan multivariabel (Regresi Linier Berganda). Hasil Penelitian menunjukkan umur termuda menikah adalah 15 tahun, Pendapatan terendah Rp. 100.000, umur menarche termuda 10 tahun, rata-rata skor pengetahuan 6,19, sikap 29,43, paparan media 1,63, pengaruh teman 5 , dukungan orang tua 2,23 , stigma 4,29 . Faktor yang mempengaruhi terjadinya pernikahan usia dini adalah pengetahuan, usia menarche, dan media (nilai $\mathrm{p}<0,05$ ). Usia menarche merupakan faktor yang paling berpengaruh terhadap usia menikah. Semakin muda umur menarche maka semakin muda umur pernikahan seseorang. Sebaiknya remaja yang sudah mengalami menstruasi menjaga kesehatan reproduksinya dengan menunda pernikahan di usia remaja.
\end{abstract}

Kata kunci: pernikahan usia dini, pengetahuan, usia menarche, media 


\section{PENDAHULUAN}

Di Indonesia 2,6\% wanita menikah pada umur kurang dari 15 tahun dan sebesar 23,9\% menikah pada umur 15-19 tahun. Permasalahan kesehatan reproduksi wanita dimulai ketika wanita mulai hidup bersama/menikah. Semakin cepat menikah maka semakin panjang masa reproduksinya (Kemenkes RI, 2013). Proporsi remaja yang telah memiliki anak meningkat menurut umur. Walaupun kurang dari $1 \%$ wanita umur 15 tahun telah menjadi ibu, $24 \%$ wanita umur 19 tahun telah menjadi ibu atau sedang hamil anak pertama. Remaja di perdesaan sebanyak $13 \%$ lebih banyak yang telah menjadi ibu dibandingkan dengan remaja di perkotaan (13\% berbanding 6\%) (BPS, 2013).

Wanita yang menikah pada usia kurang dari 18 tahun adalah akibat dari hubungan seksual yang yang terlalu muda. Perempuan yang berusia 25-49 tahun pernah melakukan hubungan seksual yang pertama kali pada saat berusia 15 tahun sebesar $8 \%$ dan wanita berusia 20 tahun sebesar $45 \%$ (BPS, 2013).

Proporsi wanita umur 20-24 tahun yang berstatus kawin atau berstatus hidup bersama sebelum umur 18 tahun di Provinsi Bengkulu meningkat setiap tahunnya. Profil Kependudukan dan Pembangunan Provinsi Bengkulu tahun 2015 usia menikah pertama menunjukkan tren yang naik dari tahun 1991 sebesar 17 tahun, 1997 sebesar 18 tahun dan tahun 2012 sebesar 14,43 tahun. Rata-rata umur menikah pertama di Provinsi Bengkulu adalah 19,79 tahun masih terdapat 7 kabupaten yang berada di bawah rata-rata yaitu Seluma $(18,96)$, Muko-muko $(19,06)$, Bengkulu Tengah dan Kepahiang $(19,13)$, Kaur $(19,35)$, Lebong $(19,43)$ dan Rejang Lebong $(19,56)$ (BPS, 2015).

Perempuan menikah pada umur 17-18 tahun di Provinsi Bengkulu sebesar 20,01\% pada tahun 2015. Kasus pernikahan anak usia anak yang berumur 11 tahun ditemukan di Kabupaten Bengkulu Tengah. Hal ini tergolong sangat muda, berisiko terhadap kesehatan reproduksi sang ibu. Dengan kejadian ini akan berakibat pada risiko bayi yang dilahirkan sang ibu akan mengalami kematian dan berisiko juga terhadap kematian sang ibu. Hal ini berdampak meningkatnya
Angka Kematian Ibu dan Angka Kematian Bayi (Firmansyah, 2016).

Faktor ekonomi yang miskin, kurangnya pendidikan, ditambah lagi daerah tempat tinggal yang berada di pedesaan merupakan faktor yang mempengaruhi alasan seseorang untuk menikah di usia yang masih tergolong muda. Penelitian yang dilakukan Hotchkiss et al., (2016) menunjukkan dalam pengambilan keputusan seseorang tersebut untuk mengenyam pendidikan ataupun menikah sangat dipengaruhi oleh faktor lingkungan dan kebiasaan masyarakat di sekitar lingkungan mereka tinggal. Pernikahan usia dini yang terjadi di Roma terjadi pada keluarga dengan ekonomi miskin, rendahnya pendidikan dan mereka tinggal di wilayah pedesaan.

Wanita dengan usia 18 tahun bertempat tinggal di pedesaan akan berisiko dua kali akan menikah usia dini dibandingkan dengan perempuan yang berusia 18 tahun bertempat tinggal di perkotaan. Anak perempuan yang tidak bersekolah akan berisiko tiga kali untuk menikah di usia muda dibandingkan dengan wanita yang menyelesaikan pendidikan sampai dengan pendidikan menengah (Evenhius \& Burn, 2014). Selain itu perempuan yang tidak sekolah tiga kali lebih mungkin untuk menikah apabila dibandingkan dengan perempuan yang menempuh pendidikan sampai sekolah menengah. Anak yang menikah usia dini lebih cenderung memilih pasangan sendiri, artinya anak perempuan memilih untuk menikah karena alasan kompleks termasuk stigma seks pra nikah dan kehamilan.

Penelitian Raj et al., (2015) menemukan dari responden yang mengalami menarche pada rentang usia 8-12 tahun berpeluang 5,56 kali menikah pada umur kurang dari 15 tahun. Sedangkan pada responden dengan usia menarche 12.1-13 tahun berpeluang 4,13 kali menikah pada usia kurang dari 15 tahun. Usia menarche berpengaruh terhadap usia menikah seseorang.

\section{METODE PENELITIAN}

Penelitian ini merupakan penelitian non eksperimental atau survei analitik dengan pendekatan cross sectional. Penelitian ini dilakukan di Kabupaten Bengkulu Tengah, 
Provinsi Bengkulu. Populasi penelitian adalah pasangan yang menikah pada bulan Januari-September 2017 yang berjumlah 300 pasangan atau 600 orang, data populasi diperoleh dari KUA Kecamatan yang ada di Kabupaten Bengkulu Tengah. Sampel pada penelitian ini berjumlah 237 orang dengan teknik pengambilan sampel yaitu Proportional Random Sampling. Kabupaten Bengkulu Tengah mempunyai 10 kecamatan, pengambilan sampel berdasarkan proporsi pasangan yang menikah pada masingmasing kecamatan.

Variabel independen pada penelitian ini yaitu status ekonomi, usia menarche, pengetahuan, sikap, paparan media, dukungan orang tua, pengaruh teman dan stigma. Variabel dependen yaitu pernikahan usia dini. Data dikumpulkan menggunakan kuesioner yang sudah diuji validitas dan reliabilitasnya. Data yang telah terkumpul dilakukan analisis deskriptif, korelasi dan regresi linier berganda.

\section{HASIL PENELITIAN}

Hasil analisis univariat terlihat pada Tabel 1. Tabel 1 menunjukkan umur termuda menikah adalah 15 tahun, pendapatan terendah $\mathrm{Rp}$ 100.000 , umur menarche termuda 10 tahun, ratarata skor pengetahuan 6,19 , sikap 29,43, paparan media 1,63 , pengaruh teman 5 , dukungan orang tua 2,23, stigma 4,29 .

Hasil analisis faktor-faktor yang mempengaruhi pernikahan usia dini di Kabupaten Bengkulu Tengah, Provinsi Bengkulu tahun 2017, dapat dilihat pada Tabel 2. Tabel 2 menunjukkan terdapat korelasi pengetahuan $(\mathrm{p}=0,000)$, usia menarche $(\mathrm{p}=0,000)$, dan paparan media $(\mathrm{p}=$ $0,016)$ dengan pernikahan usia dini.

Setelah dilakukan uji korelasi, maka selanjutnya dilanjutkan analisis uji regresi linier berganda. Variabel yang masuk dalam regresi linier berganda adalah yang memenuhi kriteria ( $\mathrm{p}<$ 0,25 ) pada analisis korelasi. Analisis multivariabel dengan regresi linier berganda dilakukan lima step yang dapat dilihat pada Tabel 3 .

Analisis regresi linier berganda dengan menggunakan metode determinan analisis backward sehingga dengan menggunakan software statistik komputer terseleksi dengan sendiri variabel yang tidak mengubah nilai $\mathrm{R}$ variabel independen sebesar $10 \%$. Analisis multivariabel menunjukkan ada 5 step analisis permodelan multivariabel. Pada tahap terakhir variabel usia menarche dan pengetahuan yang mempengaruhi usia menikah seseorang ( $p$ value $=0,000)$.

Faktor yang paling dominan mempengaruhi usia menikah adalah usia menarche artinya seiring dengan semakin lama seseorang mendapatkan menarche maka akan semakin lama pula akan menunda usia menikah. Dari hasil analisis didapatkan persamaan regresi linier berganda sebagai berikut.

Usia Menikah $=10.949+0.498$ Usia Menarche +0.343 Pengetahuan. Artinya dengan bertambahnya usia menarche dan pengetahuan seseorang akan meningkatkan usia menikah seseorang.

Tabel 1. Rata-rata Usia Menikah, Status Ekonomi, Usia Menarche, Pengetahuan, Sikap, Paparan Media, Pengaruh Teman, Dukungan Orang Tua dan Stigma

\begin{tabular}{cccc}
\hline Variabel & Mean & SD & Min-Mak \\
\hline Usia Menikah & 19,25 & 2,86 & $15-37$ \\
Status Ekonomi & $1.675 .5310,91$ & $1.147 .392,87$ & $100.000-8.000 .000$ \\
Usia Menarche & 12,40 & 1,64 & $10-21$ \\
Pengetahuan & 6.19 & 1,725 & $1-10$ \\
Sikap & 29,43 & 3,11 & $22-41$ \\
Paparan Media & 1.63 & 1,87 & $0-8$ \\
Pengaruh Teman & 5 & 1,94 & $0-10$ \\
Dukungan Orang Tua & 2,23 & 1,47 & $0-7$ \\
Stigma & 2.29 & 2 & $0-12$ \\
\hline
\end{tabular}


Tabel 2. Faktor yang Mempengaruhi Pernikahan Usia Dini di Kabupaten Bengkulu Tengah, Provinsi Bengkulu Tahun 2017

\begin{tabular}{lccc}
\hline \multicolumn{1}{c}{ Variabel } & Mean CI 95\% & r & Pvalue \\
\hline Usia Menikah & $18,84-19,66$ & & \\
Status Ekonomi & $100.000-8.000 .000$ & 0,108 & 0,098 \\
Usia Menarche & $12,17-12,64$ & 0,308 & 0,000 \\
Pengetahuan & $5,94-6,43$ & 0,213 & 0,000 \\
Sikap & $28,98-29,88$ & $-0,112$ & 0,085 \\
Paparan Media & $1,36-1,90$ & $-0,157$ & 0,016 \\
Pengaruh Teman & $4,72-5,28$ & $-0,058$ & 0,378 \\
Dukungan Orang Tua & $2,022-2,446$ & 0,049 & 0,454 \\
Stigma & $4-4,58$ & $-0,084$ & 0,195 \\
\hline
\end{tabular}

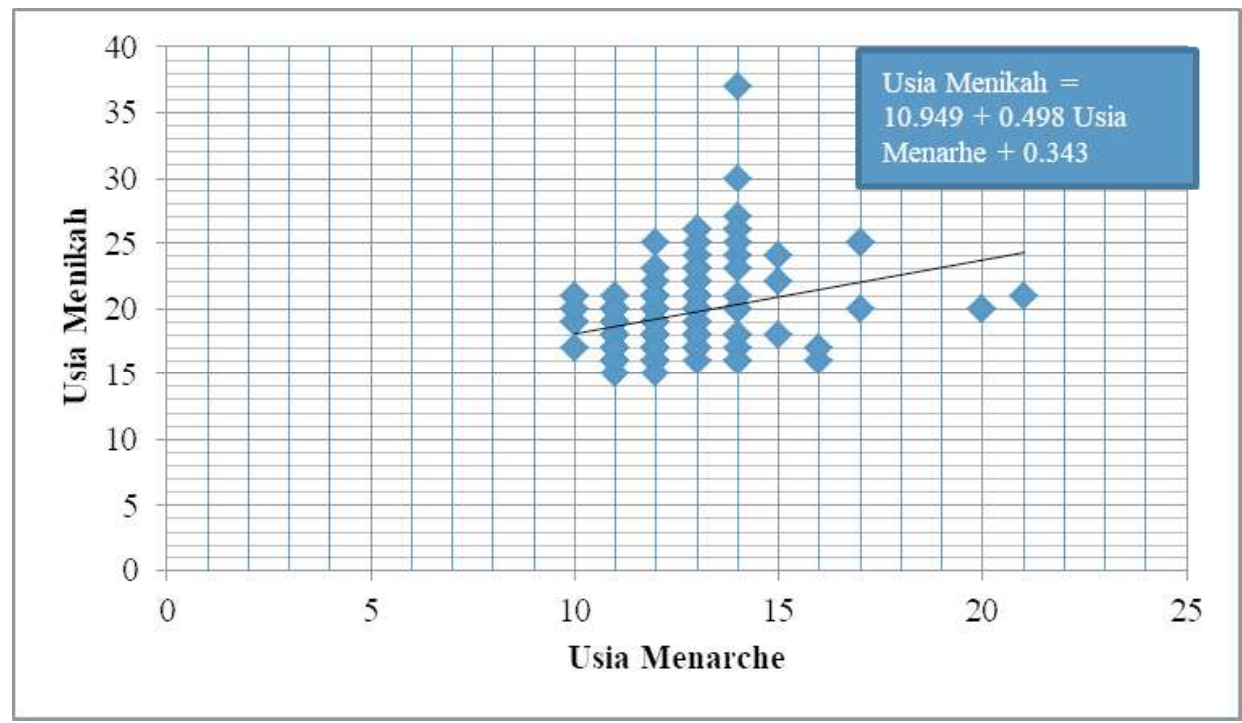

Gambar 1. Kurva Regresi linier antara Usia Menarche dengan Usia Menikah Dini

Gambar 1 menunjukkan kurva linier antara usia menarche dengan usia menikah. Apabila usia menarche seseorang lambat atau semakin dewasa seseorang mendapatkan menstruasi maka akan lambat atau menunda juga usia menikah seseorang tersebut.

\section{PEMBAHASAN}

\section{Status Ekonomi}

Hasil penelitian menemukan bahwa ratarata penghasilan responden kurang dari Upah Minimum Kabupaten Bengkulu Tengah (Rp. 1.800.000,-). Anak dari keluarga dengan status ekonomi rendah atau terlahir dari keluarga yang kurang mampu lebih memilih untuk segera menikah agar meringankan beban keluarganya. Orang tua kurang mampu membiayai kehidupan rumah tangga, kondisi ini diperberat dengan kehilangan seorang ayah. Sehingga ibu mencari nafkah sendiri (Montazeri et al., 2016).

Penelitian yang dilakukan oleh Muzaffak (2013), bahwa pendapatan orang tua memiliki hubungan yang signifikan dengan pernikahan dini. Hal yang mempengaruhi kejadian pernikahan usia muda bukan dari sudut pandang pekerjaan remaja melainkan lebih ke pekerjaan orang tua. Pekerjaan orang tua mencerminkan 
Tabel 3. Analisis Regresi Linier Berganda Faktor yang mempengaruhi Pernikahan Usia Dini

\begin{tabular}{|c|c|c|c|c|}
\hline Variabel & B & $\mathbf{R}^{2}$ & CI 95\% & p value \\
\hline \multicolumn{5}{|l|}{ Step 1} \\
\hline Ekonomi & 2.663 .007 & \multirow{7}{*}{0,168} & $0,000-0,000$ & 0,129 \\
\hline Usia Menache & 0,476 & & $0,238-0,715$ & 0,000 \\
\hline Pengetahuan & 0,268 & & $0,031-0,506$ & 0,027 \\
\hline Sikap & $-0,070$ & & $-0,193-0,054$ & 0,269 \\
\hline Paparan Media & $-0,170$ & & $-0,392-0,051$ & 0,130 \\
\hline Stigma & $-0,109$ & & $-0,302-0,085$ & 0,269 \\
\hline Constanta & 14,034 & & & \\
\hline \multicolumn{5}{|l|}{ Step 2} \\
\hline Ekonomi & 2.615 .007 & \multirow{6}{*}{0,162} & $0,000-0,000$ & 0,136 \\
\hline Usia Menarche & 0,467 & & $0,229-0,705$ & 0,000 \\
\hline Pengetahuan & 0,262 & & $0,024-0,499$ & 0,031 \\
\hline Sikap & $-0,067$ & & $-0,191-0,057$ & 0,287 \\
\hline Paparan Media & $-0,187$ & & $-0,406-0,033$ & 0,095 \\
\hline Constanta & 13,675 & & & \\
\hline \multicolumn{5}{|l|}{ Step 3} \\
\hline Ekonomi & $2,698.007$ & \multirow{5}{*}{0,157} & $0,000-0,000$ & 0,124 \\
\hline Usia Menarche & 0,464 & & $0,226-0,703$ & 0,000 \\
\hline Pengetahuan & 0,275 & & $0,039-0,511$ & 0,023 \\
\hline Paparan Media & $-0,183$ & & $-0,402-0,036$ & 0,102 \\
\hline Constanta & 11.636 & & & \\
\hline \multicolumn{5}{|l|}{ Step 4} \\
\hline Usia Menarche & 0,495 & \multirow{4}{*}{0,146} & $0,259-0,731$ & 0,000 \\
\hline Pengetahuan & 0,291 & & $0,055-0,527$ & 0,016 \\
\hline Paparan Media & $-1,52$ & & $-0,368-0,065$ & 0,169 \\
\hline Constanta & 11.560 & & & \\
\hline \multicolumn{5}{|l|}{ Step 5} \\
\hline Usia Menarche & 0,498 & \multirow{3}{*}{0,137} & $0,262=0,735$ & 0,000 \\
\hline Pengetahuan & 0,343 & & $0,118-0,568$ & 0,003 \\
\hline Constanta & 10.949 & & & \\
\hline
\end{tabular}

status sosial ekonomi dari keluarga remaja tersebut. Kehidupan seseorang sangat ditunjang oleh kemampuan ekonomi keluarga, sebuah keluarga yang berada di garis kemiskinan akan mengambil keputusan bahwa untuk meringankan beban orang tuanya maka anak wanita dinikahkan dengan orang-orang yang dianggap mampu. Pekerjaan seseorang dapat mencerminkan pendapatan, status sosial, pendidikan dan masalah kesehatan bagi orang itu sendiri.
Penelitian Sahara, Idris dan Putri (2018) menunjukkan kemiskinan berpengaruh positif dan tidak berpengaruh terhadap keputusan wanita menikah di usia $\geq 21$ tahun. Karena individu berhak untuk memutuskan menikah. Artinya pendapatan orang tua tidak berpengaruh terlalu besar terhadap pernikahan anaknya. Apabila orang tua telah memutuskan anaknya untuk menikah walaupun keadaan pendapatannya rendah tetap akan melaksanakan pernikahan. Apabila perekonomian keluarga berada di bawah 
garis kemiskinan keputusan seseorang individu untuk menikah belum tentu dengan alasan ingin meringankan perekonomian keluarga, dan sebaliknya. Perekonomian keluarga yang diatas garis kemiskinan dengan banyaknya pengangguran seseorang berasumsi untuk menikah adalah jalan terbaik.

Remaja memutuskan menikah karena remaja berpandangan dari pada mereka melanjutkan pendidikan dan bekerja namun gaji tidak sesuai dengan pendidikan yang ditempuh itu percuma. Sehingga lebih baik mereka langsung menikah dan menerima upah sesuai dengan pendidikannya bahkan ada yang pendapatannya lebih besar (Sahara, Idris dan Putri, 2018).

\section{Usia Menarche}

Hasil penelitian menemukan terdapat korelasi antara usia menarche dengan umur menikah. Semakin cepat mengalami menstruasi maka semakin cepat menikah. Usia menarche menjadi faktor yang paling berpengaruh terdapat kejadian pernikahan usia dini. Hal ini sejalan dengan temuan penelitian yang dilakukan oleh Raj et al., (2015) yang mengatakan bahwa ada hubungan antara umur menarche dengan pernikahan usia dini. Menstruasi pertama merupakan salah satu tanda bahwa seorang gadis berada pada masa pubertas. Lebih besarnya prevalensi kejadian pernikahan di usia dini dengan umur menarche cepat diperkirakan karena perilaku seksual yang didorong oleh hasrat seksual yang tidak diimbangi dengan kematangan berpikir sehingga dapat mengalami kehamilan yang tidak diinginkan yang diakhiri dengan pernikahan di usia dini.

Umur menstruasi pertama yang semakin cepat akan mempercepat seorang remaja memasuki pernikahan. Dengan demikian, pernikahan dini rawan terjadi pada remaja dengan umur menstruasi pertama yang cepat (Zai, 2012).

Penelitian lainnya menemukan responden yang tidak mengetahui batasan umur yang diperbolehkan menikah ditemukan sebanyak 345 orang $(92,49 \%)$ melakukan pernikahan dini. Selain itu pendapatan keluarga juga mempengaruhi seseorang dalam mengambil keputusan menikah, semakin rendah pendapatan keluarga semakin besar peluang untuk melakukan pernikahan usia dini (Workineh, Kibretb dan Degu, 2015).

Terdapat korelasi yang sangat kuat antara usia menarche dengan umur pertama menikah. Ditemukan sekitar $15 \%$ dari $25 \%$ wanita yang menarche pada usia kurang dari 13 tahun dan segera menikah pada usia kurang dari 13 tahun. Usia menarche berhubungan erat dengan proses reproduksi, dimana ketika seorang wanita menarche di usia dini lalu menikah mereka akan mampu melahirkan anak di usia dini juga. Ini akan menjadi sebuah fakta bahwa pernikahan usia dini membuat wanita menjadi seorang ibu di usia dini (Aryal, 2011).

\section{Pengetahuan}

Pada analisis regresi linier berganda variabel pengetahuan termasuk dalam variabel yang berpengaruh terhadap pernikahan usia dini. Sejalan dengan penelitian Dwinanda, Wijayanti dan Werdani (2015) menyatakan ada hubungan pengetahuan dengan kejadian pernikahan usia dini $(p$-value $=0,000)$. Diketahui responden yang memiliki pengetahuan rendah mengenai pernikahan usia dini memiliki risiko untuk melakukan pernikahan dini sebesar 4,286 kali dari pada responden yang memiliki pengetahuan tinggi mengenai pernikahan usia dini $(95 \% \mathrm{CI}$ : 2,082-8,825).

Pengetahuan remaja putri yang kurang akan memiliki risiko 6,19 kali akan menikah dini dibandingkan dengan remaja putri yang memiliki pengetahuan baik. Penyebabnya dikarenakan remaja putri sebagian besar berpendidikan menengah serta umur yang masih dibawah 20 tahun (usia remaja). Sehingga pola pikir masih belum matang dan dewasa dalam menerima informasi yang didapatkan dan dalam pengambilan keputusan (Pohan, 2017).

\section{Sikap}

Temuan penelitian menunjukkan tidak ada pengaruh antara sikap dengan usia menikah. Sejalan dengan temuan penelitian Ma'arif (2018) yang mana tidak terdapat hubungan pengetahuan dengan sikap responden tentang pendewasaan usia perkawinan. 
Hal ini tidak sesuai dengan penelitian Pratiwi et al., (2019) ada hubungan sikap dengan pernikahan usia dini di Kabupaten Bengkulu Tengah karena perempuan yang memiliki sikap negatif tentang pernikahan dini tidak mengetahui tentang dampak yang ditimbulkan jika melakukan pernikahan dini seperti kurangnya persiapan masing-masing pasangan dalam menghadapi masalah ekonomi, tanggung jawab, kematangan fisik, psikis dan sosial.

\section{Paparan Media}

Hasil penelitian menemukan terdapat korelasi antara paparan media dengan umur menikah seseorang $(p=0,016)$. Hal ini sejalan dengan penelitian Rahardjo \& Imron (2013) yang mengatakan responden menggunakan media untuk melihat hal-hal negatif memiliki risiko melakukan pernikahan dini 5,53 kali lebih besar dibandingkan dengan responden yang menggunakan media untuk melihat hal-hal positif ( $\mathrm{p}$ value $=0,000$ dan $\mathrm{OR}=5,53(95 \% \mathrm{CI}: 3,08$ 9,95).

Pratiwi et al., (2019) menemukan handphone sebagai alat komunikasi sangat dimanfaatkan oleh remaja untuk membuat janji jadwal pertemuan dengan teman dekatnya. Selain itu remaja juga menggunakan aplikasi media sosial untuk berkenalan dan kencan dengan lawan jenisnya dan dapat mengakses informasi negatif yang tidak pantas untuk remaja ketahui.

Remaja putri yang terpapar media massa mempunyai risiko 2,25 kali akan menikah dini dibanding remaja putri yang tidak terpapar media massa. Remaja putri yang terpapar oleh media massa berbau pornografi baik itu sengaja dan tidak sengaja. Gambar-gambar maupun video yang mereka peroleh dari media sosial. Ratarata mengakses situs-situs berbau porno dari handphone mereka. Dengan demikian remaja putri tertarik untuk untuk mencoba apa saja yang telah dilihatnya termasuk masalah seksualitas, pada akhirnya dapat menyebabkan kehamilan. Perlunya peran keluarga dalam pendampingan dan memantau anaknya dalam menggunakan media massa baik cetak, elektronik, internet (terutama media sosial) serta memberikan penjelasan pada anak terkait informasi kesehatan reproduksi secara lengkap dari orang tua sehingga anak tidak mencari informasi yang berkaitan dengan seks dari media massa (Pohan, 2017).

\section{Pengaruh Teman}

Teman sebaya tidak berpengaruh terhadap keputusan menikah seseorang. Hal ini terjadi dikarenakan menikah adalah pilihan individu bukan atas dasar pengaruh dari teman yang sudah menikah melainkan atas dasar pilihan individu yang menganggap kalau sudah menikah maka akan berkurang beban orang tua mereka dan orang tua akan bahagia. Hasil temuan wawancara responden yang menikah dini berasal dari keinginan orang tua karena merasa takut jika anaknya suatu saat melakukan perbuatan yang membuat malu nama baik orang tua (Pratiwi et al., 2019).

Teman sebaya merupakan faktor yang mempengaruhi perilaku seksual remaja. Remaja yang terpengaruh oleh teman sebaya berpeluang 1,777 kali untuk berperilaku seksual (Sari, Darmana dan Muhammad, 2018).

\section{Dukungan Orang Tua}

Pada penelitian ini tidak ditemukan adanya pengaruh peran orang tua terhadap pernikahan usia dini. Peran orangtua dalam menentukan perkawinan anak dipengaruhi oleh faktor sosial ekonomi keluarga, tingkat pendidikan keluarga, kepercayaan dan adat istiadat yang berlaku dalam keluarga dan kemampuan yang dimiliki dalam menghadapi masalah remaja. Adanya dukungan keluarga terhadap kelangsungan pernikahan usia dini tersebut pada dasarnya tidak terlepas dari tingkat pengetahuan orangtua yang dapat dihubungkan dengan tingkat pendidikan keluarga.

Orang tua mempunyai kewajiban untuk melihat, mengawasi, sikap dan perilaku remaja agar tidak terjerumus dalam pergaulan bebas dan tindakan yang merugikan diri sendiri dan lebih mengawasi pergaulan anak baik di dalam sekolah maupun di luar sekolah sehingga tidak terjadi sesuatu yang berakibat fatal yang akhirnya muncul pernikahan dini.

Peran orang tua dalam mengontrol kehidupan anak sangat berhubungan dengan pernikahan dini. Peran orang tua yang kurang 
baik berpeluang 5,78 kali mendorong anak untuk menikah di usia dini (Handayani, 2014).

\section{Stigma}

Saat ini beberapa desa di Kabupaten Bengkulu Tengah masih memandang bahwa ketika anak tidak melanjutkan sekolah maka pilihan terakhirnya adalah menikah. Hal tersebut dilakukan tanpa memperhitungkan usia anak saat itu. Meskipun tradisi ini tidak seketat dahulu, namun masih banyak orang yang melakukannya. Jika tidak menikah justru akan menjadi "aib" (beban moral) bagi keluarga, karena umur terus bertambah dan tidak memungkinkan lagi untuk bersekolah. Wanita yang berada di lingkungan masyarakat yang berbudaya kawin pada usia dini akan memiliki kesempatan lebih besar 4,64 kali dibandingkan dengan wanita yang berada di lingkungan yang tidak berbudaya kawin pada usia dini (Ayu, 2015). Penelitian Ayu (2015) juga menunjukkan kebiasaan yang terjadi pada masyarakat Kecamatan Cermee adalah ketika anak sudah menstruasi, para orang tua akan melakukan pertunangan anak perempuannya dengan anak laki-laki yang baik menurut orang tua ataupun yang menjadi pilihan anak itu sendiri. Setelah pertunangan tersebut mereka diperbolehkan untuk tinggal serumah. Rasa cemas dan takut dari orang tua serta masyarakat sekitar tentang terjadinya kehamilan di luar nikah akhirnya memutuskan pilihan lebih baik menikahkan anak mereka pada usia dini.

Pernikahan yang dilakukan di bawah usia 20 tahun adalah pernikahan yang dijodohkan atau ditunangkan. Wanita yang berusia kurang dari 15 tahun 9 dari 10 melakukan pernikahan dengan perjodohan sedangkan apabila usianya usia mencapai 18-19 tahun belum menikah akan dinikahkan oleh orang tua (Erulkar, 2013).

\section{SIMPULAN DAN SARAN}

\section{Simpulan}

Hasil korelasi yang berpengaruh terhadap umur menikah seseorang adalah pengetahuan $(p=0,000)$, usia menarche $(p=0,000)$, dan paparan media $(\mathrm{p}=0,016)$. Sedangkan yang tidak berhubungan dengan pernikahan usia dini adalah status ekonomi, sikap, pengaruh teman, dukungan orang tua, stigma.

Hasil analisis Regresi Linier berganda menunjukkan usia menarche merupakan variabel yang berpengaruh terhadap umur menikah. Semakin cepat seseorang menarche maka semakin cepat pula memutuskan untuk menikah.

\section{Saran}

Remaja yang sudah mengalami menarche sebaiknya melindungi diri dengan meningkatkan pengetahuan tentang bahaya pernikahan usia dini dan menghindari hal-hal negatif yang dapat merusak diri.

\section{DAFTAR PUSTAKA}

Aryal, T.R., 2011. Age at Menarche and Its Relation to Ages at Marriage, First-Birth and Menopause among Rural Nepalese Females. Nepal Journal of Science and Technology, 12, pp.276-285.

Ayu, D.F.A., 2015. Analisis Faktor Determinan Perempuan Tentang Pernikahan Usia Dini di Kecamaan Cermee Kabupaten Bondowoso. Jurnal Ilmiah Kesehatan Sekolah Tinggi Ilmu Kesehatan Surya Mitra Husada Kediri, 4(1), pp.1-9.

BPS, 2013. Survei Demografi dan Kesehatan Indonesia 2012. Jakarta: Badan Pusat Statistik.

BPS, 2015. Kemajuan yang Tertunda: Analisis Data Perkawinan Usia Anak di Indonesia. Jakarta: Badan Pusat Statistik.

Dwinanda, A.R., Wijayanti, A.C., Werdani, K.E., 2015. Hubungan antara Pendidikan Ibu dan Pengetahuan Responden dengan Pernikahan Usia Dini. Jurnal Kesehatan Masyarakat Andalas, 10(1), pp.76-81.

Erulkar, A., 2013. Early Marriage, Marital Relations and Intimate Partner Violence in Ethiopia. International Perspectives on Sexual and Reproductive Health, 39(1), pp.6-13.

Evenhius, M., Burn, J., 2014. Just Married, Just a Child: Child Marriage in the Indo-Pacific Region. Melbourne: Plan International Australia. 
Firmansyah, 2016. 20 Persen Perempuan di Bengkulu Menikah di Usia Muda. [online] Available at: <https://regional.kompas. com $/ \mathrm{read} / 2016 / 11 / 25 / 05383241 / 20 . \% 25$. perempuan.di.bengkulu.menikah.di.usia. muda>.

Handayani, E.Y., 2014. Faktor-faktor yang Berhubungan dengan Pernikahan Usia Dini Pada Remaja Putri di Kecamatan Tambusai Utara Kabupaten Rokan Hulu. Jurnal Maternity an, 1(5), pp.200-206.

Hotchkiss, D.R., Godha, D., Gage, A.J., Cappa, C., 2016. Risk Factors Associated with the Practice of Child Marriage among Roma Girls in Serbia. BMC International Health and Human Rights, 16(6), pp.1-10.

Kemenkes RI, 2013. Riset Kesehatan Dasar. Jakarta: Badan Penelitian dan Pengembangan Kesehatan Kementerian Kesehatan Republik Indonesia.

Ma'arif, F., 2018. Hubungan antara Tingkat Pengetauan dan Sosial Budaya dengan Sikap Remaja Terkait Pendewasaan Usia Perkawinan. Jurnal Biometrika dan Kependudukan, 7(1), pp.39-48.

Montazeri, S., Gharacheh, M., Mohammadi, N., Rad, J.A., Ardabili, H.E., 2016. Determinants of Early Marriage from Married Girls' Perspectives in Iranian Setting: A Qualitative Study. Journal of Environmental and Public Health, 2016, pp.1-8.

Muzaffak, 2013. Pengaruh Tingkat Pendidikan dan Ekonomi terhadap Pola Keputusan Orang Tua untuk Mengkawinkan Anaknya di Desa Karang Duwak Kecamatan Arosbaya Kabupaten Bangka. Paradigma, 1(1), pp.1-8.
Pohan, N.H., 2017. やFaktor yang Berhubungan dengan Pernikahan Usia Dini terhadap Remaja Putri. Jurnal Endurance, 2(3), pp.424-435.

Pratiwi, B.A., Angraini, W., Padila, Nopiawati, Yandrizal, 2019. Analisis Pernikahan Usia Dini di Kabupaten Bengkulu Tengah Tahun 2017. Jurnal Kesmas Asclepius (JKA), 1(1), pp.14-24.

Rahardjo, S., Imron, R., 2013. Determinan Pernikahan Dini di Kecamatan Kalianda. Jurnal kesehatan, IV(2), pp.357-363.

Raj, A., Ghule, M., Nair, S., Saggurti, N., Balaiah, D., Silverman, J.G., 2015. Age at Menarche, Education, and Child Marriage among Young Wives in Rural Maharashtra, India. International Journal of Gynecology \& Obstetrics, 131(1), pp.1-5.

Sahara, N., Idris, Putri, D.Z., 2018. Faktor-faktor yang Mempengaruhi Keputusan Wanita Menikah di Sumatera Barat. EcoGen, 1(3), pp.640-647.

Sari, D.N., Darmana, A., Muhammad, I., 2018. Pengaruh Faktor Predisposisi, Pemungkin, dan Pendorong Terhadap Perilaku Seksual di SMAAsuhan Daya Medan. Jurnal Kesehatan Global, 1(2), pp.53-60.

Workineh, S., Kibretb, G.D., Degu, G., 2015. Determinants of Early Marriage among Female Children in Sinan District, Northwest Ethiopia. Health Science Journal, 9(6:1), pp.1-7.

Zai, F.A., 2012. Faktor-faktor yang Berhubungan dengan Pernikahan Dini pada Remaja di Indonesia (Analisis Data Sekunder Riskesdas Tahun 2010). Skripsi. Universitas Indonesia. 